\title{
Economic Importance, Impacts and Possible Mitigation Measures of Aquatic Water hyacinth (Eichhornia crassipes Martius) in Ethiopia
}

\author{
Bogale Ayana \\ Ethiopian Institute of Agricultural Research Holeta Agricultural Research Center P.O.Box :31 Holeta Ethiopia
}

\begin{abstract}
Water hyacinth is one of invasive weed species which belongs to family Pontederiaceae which was characterized by a free floating perennial aquatic weed and one of the major challenging problems in water bodies of the tropics and sub-tropics. Therefore, the aim of this article is to identify the distribution,impacts and beneficial effects as well as the possible management practices of water hyacinth. Water hyacinth was introduced in the water bodies of the Rift Valley in 68 years ago and currently, the weed is distributed Lake Tana, Lake Abaya, Lake Koka, Koka Dam in Ethiopia.The weed affected water resources, fisheries, transportation and social structure.The wide distribution and abundance of water hyacinth has led to decreased water availability and sustainable water biodiversity in Ethiopian lakes. However, the spread of water hyacinth is threatening not only water bodies but also socioeconomic development and human health. Water hyacinth in water bodies and nearby areas of local stakeholder has negative impact on environment and also impact on aquatics biodiversity.In contrast to these, Water hyacinth is rich sources of different nutrients that provides feed for animals such as ruminants, Rabbits, Ducks, Geese, Pigs and Fish.Water hyacinth can be controlled by mechanically by machine or manual which was environmentally safe as compared to other methods. Physical control includes automatic mowers and dredgers.Biological method by using bioagents weevils which involves long term strategy and chemical involves by using herbicides 2,4 - D, Diquat and Glyphosate that can be implemented by accomplished operator.Therefore, sustainable long term management strategies should include prevention in newly infested areas. in low infested areas, integrated use of herbicides has to be developed. To contain the further spread and buildup of this weed for future infestation, these weeds should be utilized for composting and feed purposes. Besides, extensive mass awareness and community campaign especially to uproot should be implemented. Therefore, it can be summarized that human intervention is considered as the

current problem of water resource in the country and further study is needed to sustain the water resource to keep water hyacinth at economic thresh hold level.
\end{abstract}

Keywords: caused, dense mats,problems,reported,water hyacinth

DOI: $10.7176 / \mathrm{JEES} / 11-3-01$

Publication date:March $31^{\text {st }} 2021$

\section{INTRODUCTION}

Water hyacinth (Eichhornia crassipes Martius ) is one of invasive weed species which was characterized by a free floating perennial aquatic weed and one of the major challenging problems in water bodies of the tropics and sub-tropics. It is originated from the Amazon Basin and has dispersed very rapidly in many countries of Latin America, Africa, Southeast Asia and Pacific in 1950 (Petel ,2012). International Union for Conservation of Nature lists these species as one of the 100 most dangerous invasive species and as the top ten worst weeds in the world (Patel,2012). The weed is characterized by wide spreading competences, extensive dispersal mechanism, rapid reproductive potential and harsh environment tolerance adaptability (Zhang et al.,2010). Water hyacinth was appeared in Ethiopia about 53 years ago in 1965 at koka reservoir and in the Awash River. According to Fessehaie (2005) and Taye et al. (2009) other infestation in the country include Gambela Regional state, the Blue Nile from just below Lake Tana into Sudan, and Lake Ellen near Alem Tena. Water hyacinth caused wastage of water through excessive evapo-transpiration, recreational use of aquatic ecosystem, and poses of mechanical damage to hydroelectric systems. It is also responsible for drastic changes in the fisheries communities of water environments and acts as an agent for the spread of serious diseases in water bodies (Admas et al., 2017).Yirefu et al.(2017) found that Wonji sugar estate which estimated about 100,000 US\$ from 2005 to 2015 for the control of these weed. An action-implemented management program which involving mechanical, manual and chemical measures was integrated. Although in some of the infested areas these management practice were implemented, the spread of water hyacinth in the rift valley of Ethiopia was continued (Taye et al.,2009). Despite the presence of effective weevil and highly virulent fungal pathogen against water hyacinth, none of them have been utilized to control this invasive weed in Ethiopia up till now (Firehun et al.,2013). Mass awareness and community campaign especially to uproot the weed needs extensive work. Therefore, human intervention is considered as the current problem of water resource in the country and further study is needed to sustain the water resource to keep water hyacinth at economic thresh hold level. Therefore, the aim of this paper was to identify the distribution,impacts and beneficial 
effects as well as the possible management practices of water hyacinth.

\section{THE BIOLOGY AND ECOLOGY OF THE WEED \\ 2.1 The biology of the plant}

Water hyacinth belongs to family Pontederiaceae which has nine genera including Eichhornia,which has eight species of freshwater aquatics including water hyacinth(Eichhornia crassipes). Water hyacinth is a permanent, aquatic plant, free floating or anchor in low water. It can grow $100-200 \mathrm{~mm}$ sublime, expand to 1 meter while increasing in thick mats. The roots of balanced plants are long and feathery.Vegetation of water hyacinth is sparkly dim green in colour, in rosettes with characteristic upright engorged bladder-like petioles. The name water hyacinth refers to its aquatic habitat and the resemblance of the flower colour to that of the garden hyacinth. Water hyacinth, a free-floating hydrophyte, live at the air water border and form two separate canopies: leaf canopies comprise above-water structures and root canopies comprising under water structure (Dawning and Stacy,2012). The mature WH consists of roots, rhizomes, stolons, leaves, flower and fruit in cluster as indicated in figure below.

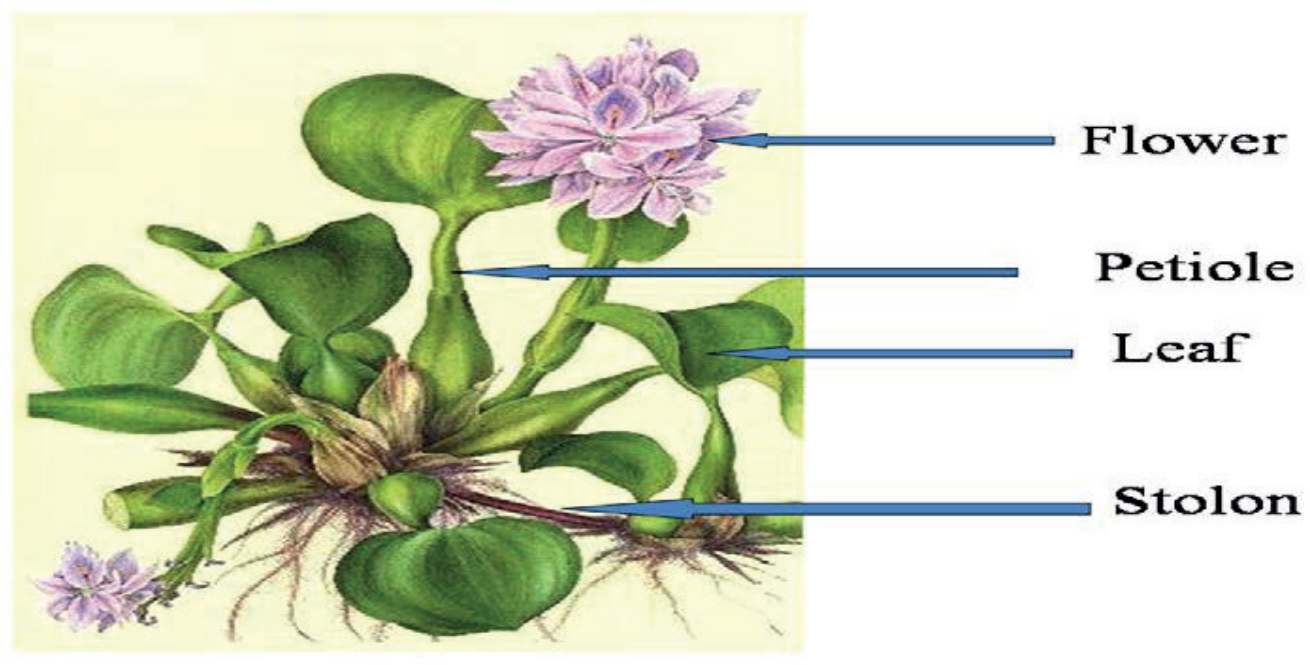

Figure 1.Morphology of water hyacinth. Source : Frehun (2017)

\subsection{Ecology and distribution}

Water hyacinth imposed ecological impact of the in Lake Tana such as dis articulation of biodiversity through deprivation of water quality and smothering of habitat by wide-ranging, permanent water hyacinth swathe. The water under the internal of widespread stationary mats of water hyacinth was nearly devoid of oxygen, predominantly late in the nighttime and early in the sunup. Jafari (2010) reported that Water hyacinth has invaded fresh water systems in over 50 countries on five continents. Melese and Samuel (2018) declared that it is especially pervasive throughout Southeast Asia, the Southern United States, Central, East and Western Africa and Central America. Invasive water hyacinths are of a large apprehension in Ethiopia, affectation exacting problems lakes,rivers, power dams, water ways, roadsides and urban green spaces with great economic and ecological consequences. It is prevalent in tropical and subtropical water bodies where nutrient levels are often high due to agricultural runoff, deforestation and insufficient waste water treatment. In recent years, water hyacinth has spread faster, and the most serious infestation is in Ethiopia particularly in Lake Tana. One of the top ten ecologically dangerous and worst invasive weed, water hyacinth (Eichhornia crassipes Martius) is aggressively infesting Lake Tana (Melese and Samuel,2018).

\subsection{Propagation methods}

Water hyacinth reproduces vegetatively through the formation of stolons, and is also sexually propagated through seeds, which can survive in water for six years making water hyacinth difficult to control. Under suitable growth conditions, the number of water hyacinths can double in one week ( Eldin , 1992). Ogutu et al (1997) reported that water hyacinth plant can produce 140 million ramets within one year, with a fresh weight of 28,000 tons . Water hyacinths are prevalent in eutrophic water bodies and can form dense grass mats covering large areas of water. Akinwande et al. (2013) studied the water hyacinth bio massin Nigerian waters, which ranged from 28.8 to 33.2 t/ha dry matter per year. The water hyacinth has a well developed root system and can absorb nutrients in the growing environment. Therefore, its material composition is closely related to the growth environment. Poddar et al.(1991) reported that water hyacinth growing in swampland areas with a nitrogen content of $2.40 \mathrm{mg} / \mathrm{L} \mathrm{had} \mathrm{a}$ nitrogen content of approximately $1.78 \%$. The nutrient composition in stems and roots is generally lower than in 
the leaf (Abdelhamid and Gabr,1991).

\subsection{Harmful effects of the weed}

\subsubsection{Harmful effects on ecology}

Water hyacinth persistent species are extensively conventional as one of the foremost cause of biodiversity loss and can have momentous possessions on resource accessibility and can restrain or improve the comparative great quantity of inhabitant species, without unavoidably being the powerful force behind community change (Wilson et al.,2005). The recent times in regional city Bahir Dar, in Lake Tana one of the recorded in world aquatic Biosphere Reserve in Ethiopia (Seid and Getnet,2017). Water hyacinth one of the floating aquatic weed and the biosphere greatest destructive weed because of its harmful possessions on marine living organism in the lakes living the water body like fisheries, frogs, other and people's livelihoods from the surrounding lakes great influences on financial especially hindering problems on water transport activity, societal, healthiness related to reduced water quality of the lake and ecological. In the surrounding areas great problem on different types of diseased exposed the likes of malaria and bilharzia and snakes, water dirty creation the supply unsuitable for drinking and other domestic use. Natural foreign invasion be individual of the forceful forces of biodiversity defeat approximately the world (Pysek and Richardson,2010). Water hyacinth has caused severe environmental defeat of freshwater water bodies (Gichuki and Odhiambo,1994). The weed out-competes the indigenous species due to its rapid reproductive ability, which poses a threat to aquatic biodiversity (Gichuki et al.,2012).

Due to its establishment, the water hyacinth also hinders the growth of vital phyto plankton, and ultimately affects fisheries and other vital aquatic animals (Villamagna and Murphy,2010). Lake of Tana created various employment opportunities for local dwellers. This lake is a good created job opportunity for the fishing industry in the town of Bahar Dar areas. The products obtained from this fishing activity supplied to hotels, restaurants, lodges etc. Water hyacinth was marked to encouragement destructively on the fitness of water side communities. Alteration of oxygen levels in the water creates and atmosphere unsuitable for fish existence, consequently resulted in dropping species.

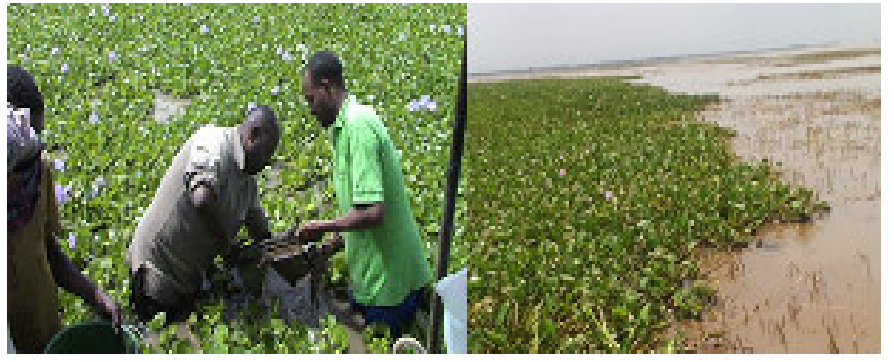

Figure 2. Impact of Water hyacinth on ecology. Source :Asmare (2017)

\subsubsection{Impacts of water hyacinth to agriculture and fisheries}

Heavy infestations of water hyacinth limit water flows in rivers and irrigation channels, interfere with irrigation equipment and have been known to cause structural damage to bridges (Jones, 2009). Decreased irrigation flow can indirectly cause loss on field crops but there can also be direct loss on paddy crops by suppressing the crop, inhibiting germination and interfering with harvesting (Patel, 2012). Similar results were reported from Yirefu et al. (2007) which stated that water hyacinth caused wastage of water through excessive evapotranspiration that would be used for sugarcane production in Ethiopia. Water hyacinth slows water flow by 40 to $95 \%$ in irrigation channels (Jones, 2009). In India in the Brahmaputra River, it has also blocked irrigation channels and obstructed the flow of water to crop fields (Patel, 2012). Moreover, in West Bengal, water hyacinth causes an annual loss of paddy rice by directly suppressing the crop, inhibiting germination and interfering with harvesting . According to the report of Rakotoarisoa (2017) at Lake Alaotra, rice fields were invaded, inhibiting the germination, suppressing the crop .

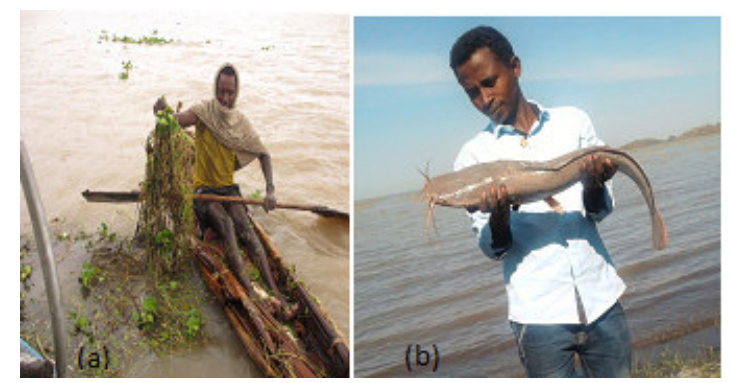

Figure 3. Fishing net entangled by water hyacinth at the landing site (a) and fishing at area free from water hyacinth (b). Source : Photo Asmare (2017). 


\subsubsection{Impacts of water hyacinth on water quality}

Floor covering of water hyacinth prevent the transfer of oxygen from the air to the water surface or decrease oxygen production by other plants and algae (Villamagna and Murphy, 2010). Water hyacinth infested areas showed low values of dissolved oxygen ranged from 1.02 to $3.60 \mathrm{mgL}-1$ ( Mevea and Boyd, 1975; Masifwa et al., 2001). The boundary areas without water hyacinth have high mean concentration of dissolved oxygen $(1.96 \pm 0.71)$

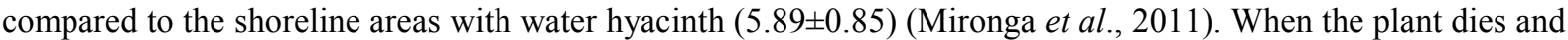
sinks to the bottom the decomposing biomass depletes oxygen content in the water body due to the high oxygen consumption of rotting plant biomass. Dissolved oxygen levels can reach dangerously low concentrations for fish that are sensitive to such changes. Furthermore, low dissolved oxygen conditions catalyse the release of phosphorus from the sediment which, in turn, accelerates eutrophication and can lead to a subsequent increase in water hyacinth or algal blooms (Bicudo and Babolola,2012). Death and decay of water hyacinth vegetation in large masses deteriorate water quality (Ndimele et al., 2011). The most apparent environmental impact of water hyacinth infestations that affect the riparian community directly is the degradation of water quality by its foul smell and debris (Cho and Tifuh, 2012). The thick mats of water hyacinth lead to an increase in water turbidity due to the constant rotting of the mat base (Villamagna and Murphy, 2010). According to Mironga et al. (2012) water hyacinth infested area showed low $\mathrm{pH}$ values ranging between $6.7-7.1$, while those without water hyacinth had higher values ranging from 7.4-7.95.

\subsubsection{Impacts of water hyacinth on hydro power plants}

Water hyacinth causes high water losses through evapotranspiration and blocking turbines. The Owen Falls hydro power scheme has suffered from the impact of the weed, hence plenty of time and money has been invested to clear and prevent the weed from entering the turbines, which may create harm and power disruption (Calvert, 2002). On Owen Falls hydro power scheme, water hyacinth caused damage to water coolers and generators, prompting the power utility company to switch off generators for maintenance, and about 15 Megawatts of electricity were lost causing power cut in an urban area of Ethiopia (Yirefu et al.,2017). Many large hydro power schemes are suffering from the effects of water hyacinth. It is now a major problem in some of the world's major dams. Dams feeding the city of Harare have pronounced infestations of the weed (Mujere, 2016). The Owen Falls hydro power scheme on Lake Victoria is a victim of the weeds (Minakawa et al., 2005). The hydro power dams on the Shire River in Malawi also frequently forced to stop production due to clogging of the water cooling system by this weed (Wise et al., 2017). The Kariba dam which straddles the Zambia - Zimbabwe boundary on the Zambezi River and Koka Lake hydro power dam in Ethiopia suffer from the rapid reproduction of water hyacinth (Senayit et al., 2004). In addition, Ethiopian Electric Power Corporation has reported this plant as a problem and disrupting their operation at the three hydro power stations located along the Awash River (Tegene and Ayele,2014).

\subsubsection{Impacts of water hyacinth on human health}

Floating dense mats of water hyacinth support organisms that are harmful to human health.The ability of its mass of fibrous, free-floating roots and semi submerged leaves and stems decrease water currents and helps increase breeding habitat for malaria causing anopheles mosquito as evidenced in Lake Victoria (Minakawa et al., 2005). According to Yirefu et al. (2007) based on the information obtained from Wonji Hospital malaria is still one of the major fatal diseases in the area that is supported by the stagnant water resulted from the impeding effect of water hyacinth. Mansonioides mosquitoes, the vectors of human lymphatic disease causing nematode Brugia, breed on this weed (Varshney and Shushilkumar, 2008). Snails serving as a vector for the parasite of Bilharzia reside in the tangled mat of this weed (Bicudo and Babalola, 2012). The weed also blocks access to water points and has been linked to an increase in cholera and typhoid. For example, from period of 1994 to 2008, Nyanza Province in Kenya, which borders Lake Victoria accounted for a larger proportion of cholera cases than expected given its population size $38.7 \%$ of cholera cases versus $15.3 \%$ of national population (Feikin et al., 2010). The increased incidences of crocodile attacks have been attributed to the heavy infestation of the weed which provides cover to the reptiles, poisonous snakes, crocodiles and hippos (Patel, 2012).

\subsubsection{Impacts of water hyacinth on water transport and recreation}

Access to harbors and docking areas can be seriously hindered by mats of water hyacinth. Canals and fresh water rivers can become impassable as they clog up with densely intertwined carpets of the weed (Ndimele et al., 2011).The entire Abo and Moundja Moussadi creeks have been rendered and impassable by the mats of the weed which leads to a complete halt in all the socioeconomic activities (Mujingni, 2012). According to the report of Cho and Tifuh (2012) riparian communities in Cameroon, as part of their social activities like recreational benefits from the river; boat racing; swimming and site seeing were not possible in water hyacinth infested areas. Based on the study of Mujere (2016) water hyacinth was becoming a serious hazard to lake transport on Lake Victoria as large floating mats of water hyacinth form and this causes difficulty in navigation. This has grave implications such as failure to transport essential commodities from one landing site to another. In Uganda, residents of some islands such as Kasanje and Busi depend on water transport to take the sick to hospitals located in the mainland, for example, in Entebbe but when the weed blocks the way, deaths are common (Mujere, 2016). 


\section{Chemical composition of water hyacinth}

The composition of WH is characterized by low dry matter and high CP and ash contents. Light green leaves and petioles of the immature plant are softer and contain a higher proportion of protein than those of the mature plant (Men and Yamasaki, 2005). The leaf protein content is higher than sweet potato leaf while the protein content in whole plant is considerable higher than grasses such as elephant grass (Harley et al., 1996) and can be used as a protein supplement of low quality diets. Protein in leaves contains most essential amino acids and is particularly rich in glutamine, asparagine and leucine. Chemical composition of WH varies with season, habitat (Poddar et al.,1991) as well as with harvesting frequency. Under warm weather conditions like in Vietnam, forages mature more rapidly and cell walls become highly lignified. Protein concentration is high in the immature forage but declines with advancing maturity. Lignin, followed by silica and cutin, are the primary limiting factors of digestibility. Lignin content of WH in the range from 7 to $10 \%$ has been reported while silica has varied widely from 0.5 to $5 \%$ (Abdelhamid and Gabr, 1991). As nutrient composition of $\mathrm{WH}$ is generally related to nutrient availability in the habitat where the plants are growing, WH grown in sewage has high protein and mineral contents (McDonald et al., 1978).

\section{Importance of water hyacinth 4.1 Animal feed}

Water hyacinth is an important animal feed that can be used as fresh or wilted to animals. The entire plant was chopped in to smaller sizes can be used as feed stuffs for both ruminants and monogastrics animals. According to Mukherjee and Nandi (2004) Water hyacinth contains high levels of cellulose and hemicellulose which could serve as energy sources for ruminants. Fresh WH has been utilized as partial substitution of para grass (Brachiaria mutica) in diets to cattle (Thu,2011) and has given better growth than after wilting when fed to goats (Aregheore and Cawa, 2000). Supplementation of wilted WH in a rice straw-based diet had positive effect on intake and growth of beef cattle (Islam et al., 2009). Daily live weight gain was approximately $500 \mathrm{~g}$ when $30 \%$ dried WH has been included in the basal diet of wheat straw at a fixed amount of concentrates (Parashar et al., 1999). As water hyacinth has a low dry matter content, wilting is generally preferred to reduce silage losses (McDonald et al., 2011). Water hyacinth can be successfully ensiled with the addition of molasses, rice bran, cassava root as well as with organic acids, and the silages have been accepted by ruminants. An ensiled mixture of WH, rice straw, urea and molasses has been fed to dairy cattle resulting in an increase of milk yield (Chakraborty et al., 1991). Baldwin et al.(1975) and Aburaya et al.(1980) have been reported utilization of both wilted and ensiled WH as a feed for sheep. Although wilted WH has not been recommended as a sole feed for sheep, it can replace up to $50 \%$ of the concentrates in complete diets (Abdelhamid and Gabr,1991). Water hyacinth residues after mechanical extraction of the juice can be used in the diet of fattening buffalo calves. Water hyacinth accounted for $35 \%$ of diet, while the remaining was concentrates $(61 \%)$, molasses $(2 \%)$ and a mineral mixture $(1 \%)$. Feed conversion efficiency was higher with the $\mathrm{WH}$ residues compared to a similar level of Egyptian clover (Trifolium alexandrinum).

In Vietnam, a replacement of concentrates in pig diets by cooked or fresh WH reduced organic matter digestibility and digestible energy content without affecting feed intake and performance but the use of concentrates were reduced up to 6\% in pig diets (Manh et al., 2002b). Manh et al. (2002a) also found that WH at a $15 \%$ DM content was successfully preserved by adding $4.5 \%$ of molasses on a Farmyard basis. Due to its low cost, ensiled WH could be economically acceptable by small holder farms.

\subsubsection{Food for Rabbits}

The University of Florida successfully fed pelleted WH to rabbits. Waste water grown WH completely or partially replaced alfalfa without effects on growth rate and reproductive parameters. The optimum inclusion level of WH will depend on the feedstuff replacement in a complete diet. According to Thu and Dong (2009) the replacement of para grass with WH up to $60 \%$ in rabbit diets improved feed utilization, growth performance and economic returns .

\subsubsection{Food for Ducks and geese}

Aquatic plants such as WH or duckweed is an alternative in duck production system in the Mekong Delta of Vietnam when the birds are confined and fed traditional diets such as unhulled rice, broken rice and rice bran (Men and Yamasaki, 2005; Sotolu, 2010). Men and Yamasaki (2005) found that a replacement of 5 to $25 \%$ of a commercial diet by fresh WH to growing ducks decreased performance but was economically profitable due to the lower feed cost. In China, WH has been harvested from waste water treatment ponds and used as duck feed to evaluate egg-laying ratio and egg quality. Although feed conversion ratios were almost the same, the inclusion of WH in duck diets gave higher daily feed intake, egg laying ratio and egg quality compared to the un supplemented control diet. Feikin et al.(2010) reported that 20 Chinese goslings ( 9 weeks of age) fed concentrates with free access to a $185 \mathrm{~m}$ pond in Florida covered by WH were able to clear approximately one-third of the WH after 8 weeks and also had a higher than goslings without access to $\mathrm{WH}$. 


\subsubsection{Food for Fish}

Water hyacinth has been recommended as a feed source for herbivorous or omnivorous fresh water fish (Hertrampf and Piedad-Pascual, 2000). Nevertheless, the relatively high fiber content may limit its use in tilapia feeds (Buddington,1980). El-Sayed (2003) has evaluated on the effects of silage WH for Nile tilapia fingerlings using $5 \%$ sugar cane molasses as an additive. The results indicate that the silage gave better performance than fresh WH as a replacement of wheat bran at a substitution level of 10 to $20 \%$. The most suitable inclusion level will depend on the farming system. With a basal diets such as rice bran, broken rice as well as chicken manure, the supplementation of WH can be as high as $50 \%$ in the fish diet (Hertrampf and Piedad, 2000). A maximum level of only $10 \%$ seems to be feasible as partial replacement of protein in a formulated feed based on fish meal and vegetable oil cake (Hertrampf and Piedad, 2000).

\subsection{Water purification}

Water hyacinth has a capacity to remove contaminants from polluted bodies of water (Chen et al., 1989). Many contaminants such as total suspended solids, dissolved solids, nitrogen, phosphorous, heavy metals, etc. as well as biochemical oxygen demand have been minimized using WH (Gupta et al., 2012). Nitrogen and phosphorus removal capacity from dairy waste water was found to be fastest in $\mathrm{WH}$, followed by Lemna minor and Azolla pinnata (Tripathi and Upadhyay, 2003). Nitrogen removal by WH, Lemna minor and Azolla pinnata were 72, 63 and $60 \%$, respectively, while 63,59 and $56 \%$ of phosphorus were removed by these macrophytes. When WH growing in wetlands receiving domestic and industrial waste water, concentrations of $\mathrm{Cu}, \mathrm{Cd}, \mathrm{Ni}, \mathrm{Pb}$ and $\mathrm{Zn}$ in the roots were 3 to 15 times higher than those in the shoots. This showed that roots may act as a natural biosorbent (Low et al., 1994).

\subsection{Other uses of water hyacinth}

Water hyacinth has been used as mulch and compost and for paper-making (Nolan and Kirmse, 1974) and biogas generation (Kivaisi and Mtila, 1997). The fiber from the petioles can be used to make rope, baskets, carpet, etc. (Malik, 2007). According to Oroka (2012) and Elserafy et al.(1980)Water hyacinth seems to be a good source of organic carbon and has been used as an organic fertilizer. Positive responses of WH compost on growth and yield of Brassica juncea (Nuka and Dubey , 2011). Water hyacinth, as a substrate for oyster mushroom (Pleurotus sajor$c a j u$ ) cultivation at a proportion of $25 \%$ with rice straw, increased yield by $19 \%$ compared to pure rice straw. The possible use of WH pulp to produce grease proof paper was reported by Goswami and Saikia (1994) and in the Khmer community in the Mekong Delta of Vietnam, one of the sources of income come has been the sale of WH flowers (Thu,2012). Using WH to remove nutrients from water bodies and to produce biogas is technically feasible options for the control of WH .

As rapid industrial development, there is a need for environmentally sustainable energy sources. Utilization of lingocellulosic material from WH biomass has been considered for production of ethanol in many tropical regions of the world (Aswathy et al., 2010). Tran et al.(2011) reported that using combinations of WH and pig manure to produce biogas and generate electric power.

\section{Control methods}

\subsection{Mechanical control}

Mechanical, chemical and biological control methods are commonly used to control WH but no one method is suitable for all situations. Mechanical control includes harvesting by hand or machine (Villamagna and Murphy, 2010). The use of machinery to remove WH from water bodies is the most effective non-polluting control method especially in critical areas such as hydro-electric dams and ports. The main advantage to the use of mechanical harvesting is the simultaneous removal of nutrients and pollutants from the water body and may therefore act as a means of slowing or even reversing eutrophication. Mechanical harvesting of WH has also resulted in rapid increases in dissolved oxygen and improved suitability of the habitat to support fish. However,it requires recurring efforts involving machine and labour inputs. Mechanical removal with harvesters is also slow and therefore not suitable for large mats. Studies have shown that costs of mechanical harvesting are on average US\$ 600 to 1,200 per hectare about six times more expensive than chemical treatment using glyphosate.

\subsection{Biological control}

Biological control is a long-term direct practice and is suggested for its consumer friendly and provides a sound financial and sustainable management way of WH. These techniques involve the host precise established challenger to decrease the inhabitant's attentiveness of the weed. Repots of Cilliers et al.(1996) indicated that numerous insects like weevils, moth and fungi are use as control agents for the water hyacinth. In Australia, the technique has been successful through ordinary discharge of the weevils Neochetina eichhorniae ,Neochetina bruchi and the moth Sameodes albiguttalis effectively reduced the inhabitants' density of water hyacinth. Similarly,Lake Victoria organic control under surveillance and regular monitor has been productively practical to 
defeat water hyacinth .

\subsection{Physical control}

Physical control method is regularly worn roughly the humankind.It is very select to be appropriate and use equipment such as automatic mowers and dredgers. The method can only resolve little infected areas hence are not a sustainable long term solution. It requires fleet of motor vehicle to move immense quantities of water hyacinth after it has being impassive and the mats of water hyacinth can have a density of up to 200 tons per acre (Harley et al.,1996).

\subsection{Chemical control}

This method uses herbicides such as 2, 4-D, Diquat and Glysophate to manage water hyacinth . It is most excellent for little invasion area not big areas. Appliance is ready each on the earth or air with accomplished operator. The technique has ecological and healthiness alarm as herbicides can be injurious predominantly source used for expenditure and wash. Apart from the three control methods, Harley et al. (1996) recommended to if the amount of nutrients incoming any water body is decrease, this continual reduce the invasion and expansion of the water hyacinth.

\section{CONCLUSION}

Water hyacinth is one of invasive weed species which was characterized by a free floating perennial aquatic weed and one of the major challenging problems in water bodies of the tropics and sub-tropics.It had impact on social, environmental and economy that hinders fishing operation. The major influencing negative factors include; hindrance to water transport, blockage of irrigation canals and rivers, disrupting of electric power operation, increase loss of water due to evapotranspiration, causing flooding and human health problem, interference fishing activities, navigation, irrigation, livestock watering, and reduction of water biodiversity.Despite of its impact, Water hyacinth provides economic importance of compost making and rich sources of different nutrients.It is palatable and consumed by many animals in well prepared forms. Recent findings indicated that the use of bio control agent is the most effective, economical and sustainable management approach for water hyacinth. In Ethiopia, management of this invasive weed is still under initial stage. However, the use of biological control agent to reduce the level of water hyacinth at the national level has received a big attention and researchers have become engaged in conducting research. Therefore, sustainable long term management strategies should include prevention in newly infested areas. in low infested areas, integrated use of herbicides has to be developed. To contain the further spread and buildup of this weed for future infestation, these weeds should be utilized for composting and feed purposes. Besides,extensive mass awareness and community campaign especially to uproot should be implemented. Therefore, it can be concluded that human intervention is considered as the current problem of water resource in the country and further study is needed to sustain the water resource to keep water hyacinth at economic thresh hold level. Moreover,human intervention is considered as the current problem of water biodiversity in the country and further investigation is needed to sustain natural biodiversity.

\section{REFERENCES}

Abdelhamid, A.M. and Gabr, A.A., 1991. Evaluation of water hyacinth as a feed for ruminants. Archiv für Tierernaehrung, 41(7-8):745-756.

Abdelhamid, A.M. and Gabr, A.A., 1991. Evaluation of water hyacinth as a feed for ruminants. Archiv für Tierernaehrung, 41(7-8):745-756.

Abouraya, A.K., Hathout, M.K., El-Talty, Y.L. \& Abdel-Khabir, A.M. (1980). Utilization of (Eichhornia crassipes), a clonal aquatic plant. Molecular ecology 2010, 19:1774-1786.

Akinwande, V.O., Mako, A.A. and Babayemii, O.J., 2013. Biomass yield, chemical composition and the feed potential of water hyacinth (Eichhornia crassipes, Mart. Solms-Laubach) in Nigeria. International Journal of AgriScience, 3(8):659-666.

Aregheore, E.M. and Cawa, K., 2000. Voluntary intake by crossbred Anglo-Nubian goats of water hyacinth (Eichhornia crassipes) fed in two states plus guinea grass (Panicum maximum) in confinement. Scientia Agriculturae Bohemica, 31(4) :261-271.

Asmare, E., 2017. Current Trend of Water Hyacinth Expansion and Its Consequence on the Fisheries around North Eastern Part of Lake Tana...Ethiopia. J Biodivers Endanger Species 5: 189

Aswathy, U.S., Sukumaran, R.K., Devi, G.L., Rajasree, K.P., Singhania, R.R. and Pandey, A., 2010. Bio-ethanol from water hyacinth biomass: an evaluation of enzymatic saccharification strategy. Bioresource technology, 101(3):925-930.

Balmford, A. and Bond, W., 2005. Trends in the state of nature and their implications for human well being. Ecology Letters, 8(11):1218-1234.

Bicudo, D.D.C., Fonseca, B.M., Bini, L.M., Crossetti, L.O., Bicudo, C.E.D.M. and ARAÚJO - JESUS, 
T.A.T.I.A.N.E., 2007. Undesirable side - effects of water hyacinth control in a shallow tropical reservoir. Freshwater biology, 52(6) :1120-1133.

Borokini, T.I. and Babalola, F.D., 2012. Management of invasive plant species in Nigeria through economic exploitation: lessons from other countries. Management of Biological Invasions, 3(1), p.45.

Calvert, P., 2002. Water hyacinth control and possible uses. Technical Brief. International Technology Development Center, UK Available at http://ow. ly/TjgpJ.

Chen, Y.-L., Chiang, H.-C., Wu, L.-Q. \& Wang, Y.-S. (1989). Residues of glyphosate in an aquatic environment after control of water hyacinth (Eichhornia crassipes). Journal of Weed Science and Technology 34(2) :117122.

Cho, M.E. and Tifuh, J., 2012. Quantification of the impacts of water hyacinth on riparian communities in Cameroon and assessment of an appropriate method of control: the case of the Wouri River Basin.

Cilliers, C.J., Campbell, P.L., Naude, D.S.S.N. and Neser, S., 1996. An integrated water hyacinth control programme on the Vaal River, in a cool, high altitude area in South Africa.

Downing - Kunz, M.A. and Stacey, M.T., 2012. Observations of mean and turbulent flow structure in a free floating macrophyte root canopy. Limnology and Oceanography: Fluids and Environments, 2(1) :67-79.

Elserafy, Z.M., Sonbol, H.A. and Eltantawy, I.M., 1980. The problem of water hyacinth in rivers and canals: I. Production of compost from plant. Soil science and plant nutrition, 26(1) :135-138.

Feikin, D.R., Tabu, C.W. and Gichuki, J., 2010. Does water hyacinth on East African lakes promote cholera outbreaks?. The American journal of tropical medicine and hygiene, 83(2) :370-373.

Feikin, D.R., Tabu, C.W. and Gichuki, J., 2010. Does water hyacinth on East African lakes promote cholera outbreaks?. The American journal of tropical medicine and hygiene, 83(2):370-373.

Fessehaie, R., 2005. Water hyacinth (Eichhornia crassipes): A Review of its weed status in Ethiopia. Arem (Ethiopia).

Firehun, Y., Struik, P.C., Lantinga, E.A. and Taye, T., 2013. Joint use of insects and fungal pathogens in the management of water hyacinth (Eichhornia crassipes): Perspectives for Ethiopia.J Aquat Plant Manage, $51: 109-121$.

Ganguly, A., Chatterjee, P.K. and Dey, A., 2012. Studies on ethanol production from water hyacinth-A review. Renewable and Sustainable Energy Reviews, 16(1) :966-972.

Gichuki, J. and Odhiambo, W., 1994. The role of macrophytes in the economy of the lower Sondu-Miriu River of Lake Victoria. African Journal of Tropical Hydrobiology and Fisheries, 5(2) :69-78.

Gichuki, J., Omondi, R., Boera, P., Okorut, T., Matano, A.S., Jembe, T. and Ofulla, A., 2012. Water Hyacinth Eichhornia crassipes (Mart.) Solms-Laubach dynamics and succession in the Nyanza Gulf of Lake Victoria (East Africa): implications for water quality and biodiversity conservation. The Scientific World Journal : 106-429.

Gupta, P., Roy, S. and Mahindrakar, A.B., 2012. Treatment of water using water hyacinth, water lettuce and vetiver grass-A review. system, Resources and Environment 2(5): 202-215.

Harley, K.L.S., Julien, M.H. and Wright, A.D., 1996. Water hyacinth: A tropical world wide problem and methods for its control.proceedings of the first meeting of the International Water Hyacinth Consortium, World Bank pp: $18-19$.

Hertrampf, J.W. and Piedad-Pascual, F., 2000. Krill meal. In Handbook on ingredients for aquaculture feeds . Springer, Dordrecht.Kluwer Academic Publishers, The Netherlands. pp. 221-228.

Islam, S., Khan, M.J. and Islam, M.N., 2009. Effect of feeding wilted water hyacinth (Eichhornia crassipes) on the performance of growing bull cattle. Indian Journal of Animal Sciences, 79(5):494-497.

Jafari, N., 2010. Ecological and socio-economic utilization of water hyacinth (Eichhornia crassipes Mart Solms). Journal of Applied Sciences and Environmental Management, 14(2).

Jones, R.W., 2009. The impact on biodiversity, and integrated control, of water hyacinth, Eichhornia crassipes (Martius) Solms-Laubach (Pontederiaceae) on the Lake Nsezi-Nseleni River System (Doctoral dissertation, Rhodes University).pp.115

Low, K.S., Lee, C.K. and Tai, C.H., 1994. Biosorption of copper by water hyacinth roots. Journal of Environmental Science \& Health Part A, 29(1):171-188.

Malik, A., 2007. Environmental challenge vis a vis opportunity: the case of water hyacinth. Environment international, 33(1):122-138.

Manh, L.H., Dung, N.N.X. and Yamasaki, S., 2002, November. Water hyacinth (Eichhornia crassipes): Ensiling techniques, its composition and intake of pigs. In Proceedings of the 2002 annual workshop of JIRCAS Mekong Delta Project-Development of new technologies and their practice for sustainable farming systems in the Mekong Delta.pp. 168-175.

Masifwa, W.F., Twongo, T. and Denny, P., 2001. The impact of water hyacinth, Eichhornia crassipes (Mart) Solms on the abundance and diversity of aquatic macroinvertebrates along the shores of northern Lake Victoria, Uganda. Hydrobiologia, 452(1-3) :79-88. 
McDonald, P.E., RA, G., JFD, M. and CA, S., LA and Wilkinson RG 2011. Animal nutrition. Seventh Edition, Pearson Education Limited, Edinburgh Gate, Harlow, Essex CM20 2JE, England. pp.692.

McVea, C. and Boyd, C.E., 1975. Effects of Waterhyacinth Cover on Water Chemistry, Phytoplankton, and Fish in Ponds 1. Journal of Environmental Quality, 4(3) :375-378.

Melese, W. and Samuel, S., 2018. Impact of Water Hyacinth, Eichhornia crassipes (Martius)(Pontederiaceae) in Lake Tana Ethiopia: A Review. J Aquac Res Development, 9(520): 2155-9546

Melese, W. and Samuel, S., 2018. Impact of Water Hyacinth, Eichhornia crassipes (Martius)(Pontederiaceae) in Lake Tana Ethiopia: A Review. J Aquac Res Development, 9(520), p.2.

Men, B.X. and Yamasaki, S., 2005. Use of water hyacinth as partial supplements in diets of growing crossbred common ducks. In Proceedings of the Workshop on the Technology Development for Livestock Production, JIRCAS-CTU.pp. 83-90.

Minakawa, N., Sonye, G., Dida, G.O., Futami, K. and Kaneko, S., 2008. Recent reduction in the water level of Lake Victoria has created more habitats for Anopheles funestus. Malaria journal, 7(1), p.119.

Mironga, J.M., Mathooko, J.M. and Onywere, S.M., 2011. The effect of water hyacinth (Eichhornia crassipes) infestation on phytoplankton productivity in Lake Naivasha and the status of control. Journal of Environmental Science and Engineering, 5(10).

Mujere, N., 2016. Water Hyacinth: Characteristics, Problems, Control Options, and Beneficial Uses. In Impact of Water Pollution on Human Health and Environmental Sustainability.pp. 343-361.

Mukherjee, R. and Nandi, B., 2004. Improvement of in vitro digestibility through biological treatment of water hyacinth biomass by two Pleurotus species. International biodeterioration \& biodegradation, 53(1) :7-12.

Ndimele, P.E., Kumolu-Johnson, C.A. and Anetekhai, M.A., 2011. The invasive aquatic macrophyte, water hyacinth \{Eichhornia crassipes (Mart.) Solm-Laubach: Pontedericeae\}: problems and prospects. Research Journal of Environmental Sciences, 5(6) :509-520.

Nuka, L. and Dubey, V. ,2011. Response of water hyacinth manure on growth attributes and yield in Brassica juncea. Journal of Central European Agriculture 12(2):336-343.

Oroka, F.O., 2012. Water hyacinth-based vermicompost on yield, yield components, and yield advantage of cassava+ groundnut intercropping system. Journal of Tropical Agriculture, 50(1) :49-52.

Parashar, S.K., Rajora, N.K. and Jain, L.S., 1999. Utilization of water hyacinth (Eichhornia crassipes) by growing crossbred calves. Indian Journal of Dairy Science (India).52(5): 320-323

Patel, S., 2012. Threats, management and envisaged utilizations of aquatic weed Eichhornia crassipes: an overview. Reviews in Environmental Science and Bio/Technology, 11(3) :249-259.

Poddar, K., Mandal, L. and Banerjee, G.C., 1991. Studies on water hyacinth(Eichhornia crassipes)- chemical composition of the plant and water from different habitats. Indian Veterinary Journal, 68(9) :833-837.

Pyšek, P. and Richardson, D.M., 2010. Invasive species, environmental change and management, and health. Annual review of environment and resources, 35:25-55.

Rakotoarisoa, T.F., 2017. Use of Water Hyacinth (Eichhornia Crassipes) in Poor and Remote Regions: A Case Study from Lake Alaotra, Madagascar (Doctoral dissertation, Universität Hildesheim).

Seid, A. and Getenet, B., 2017. Exotic and Invasive Plants: Water Hyacinth. In Social and Ecological System Dynamics.pp. 257-279.

Senayit, R., Agajie, T., Taye, T., Adefires, W. and Getu, E., 2004. Invasive alien plant control and prevention in Ethiopia. Pilot Surveys and Control Baseline Conditions. Report submitted to EARO, Ethiopia and CABI under the PDF B phase of the UNEP GEF Project-Removing Barriers to Invasive Plant Management in Africa. EARO, Addis Ababa, Ethiopia.

Sotolu, A.O., 2010. Digestibility value and nutrient utilization of water hyacinth (Eichhornia crassipes) meal as plant protein supplement in the diet of Clarias gariepinus (Burchell, 1822) juveniles. American-Eurasian Journal of Agricultural \& Environmental Sciences, 9(5):539-544.

Taye, T., Rezene, F., Firehun, Y., Derje, T. and Tamado, T., 2009. Review invasive weed research in Ethiopia. Increasing crop production through improved plant protection, 2 :381-407.

Tegene, S. and Ayele, N., 2014. Prevalence and intensity of water hyacinth infestation in the water bodies of Rift Valley, Ethiopia. The Journal of Agriculture and Natural Resources Science, 1(2) :118-126.

Thu, N.V. and Dong, N.T.K., 2009. A study of water hyacinth (Eichhornia crassipes) as a feed resource for feeding growing rabbits. Preston, $R$., et al.nternational Conference on Livestock, Climate Change and the Environment. 16-18 October 2009, An Giang University, Vietnam.

Thu, N.V., 2011. Effects of water hyacinth (Eichhornia crassipes) in local cattle diets on nutrient utilization, rumen parameters and microbial protein synthesis. In SAADC 2011 strategies and challenges for sustainable animal agriculture-crop systems, Volume III: full papers. Proceedings of the 3rd International Conference on sustainable animal agriculture for developing countries, Nakhon Ratchasima, Thailand, 26-29 July, 2011.pp. 422-426. Suranaree University of Technology.

Tran, T.T., Nguyen, V.D., Do, D.N., Nguyen, H.P. and Choi, J., 2011. Assessment of electric power generation 
via water hyacinths and agricultural waste. Journal of Energy and Power Engineering, 5(7):627-631

Tripathi, B.D. and Upadhyay, A.R., 2003. Dairy effluent polishing by aquatic macrophytes. Water, Air, and Soil Pollution, 143(1-4) :377-385.

Varshney, J.G. and Sushilkumar, M.J., 2008. Current status of aquatic weeds and their management in India. In Proceedings of Taal2007: the 12th world lake conference pp. 1039-1045.

Villamagna, A.M. and Murphy, B.R., 2010. Ecological and socio - economic impacts of invasive water hyacinth (Eichhornia crassipes): a review. Freshwater biology, 55(2) :282-298.

Wise, R.M., Van Wilgen, B.W., Hill, M.P., Schulthess, F., Tweddle, D., Chabi-Olay, A. and Zimmermann, H.G., 2017. The economic impact and appropriate management of selected invasive alien species on the African continent.

Yirefu, F., Struik, P.C., Lantinga, E.A. and Tessema, T., 2017. Occurrence and diversity of fungal pathogens associated with water hyacinth and their potential as biocontrol agents in the Rift Valley of Ethiopia. International journal of pest management, 63(4) :355-363.

Yirefu, F., Tafesse, A., Gebeyehu, T. and Tessema, T., 2007. Distribution, impact and management of water hyacinth at Wonji-Shewa Sugar Factory. Eth J Weed Manag, 1(1) :41-52.

Zhang, Y.Y., Zhang, D.Y. and Barrett, S.C., 2010. Genetic uniformity characterizes the invasive spread of water hyacinth (Eichhornia crassipes), a clonal aquatic plant. Molecular ecology, 19(9) :1774-1786. 